\title{
Iwona Borowik*
}

\section{WŁADZE MIEJSKIE A POSZUKIWANIA DOBREJ PRZESTRZENI PUBLICZNEJ}

\begin{abstract}
Abstrakt. Artykuł porusza zagadnienie relacyjności między przestrzenią publiczną (jej formą funkcją architektoniczną) miasta i władzami miejskimi oraz mieszkańcami. Dotyka kwestii poczucia odpowiedzialności mieszkańców za ich miasto. Szkicuje problem prywatyzowania oraz fragmentacji przestrzeni publicznej miasta. Podejmuje zagadnienie poszukiwania dobrej miejskiej przestrzeni publicznej poprzez wzmacnianie jej tożsamości architektonicznej i estetycznej, szczególnie istotnej w przypadku ważnej symbolicznie i prestiżowo przestrzeni centralnej miasta.
\end{abstract}

Słowa kluczowe: miasto (postsocjalistyczne), przestrzeń architektoniczna, (dobra) przestrzeń publiczna, prywatyzacja i fragmentacja przestrzeni publicznej, park kulturowy.

Miasto jest złożoną strukturą społeczną, kulturową i przestrzenną. Ma swój określony początek, ciągłość i trwanie, czasem koniec, ale i odrodzenie. Siła miasta tkwi w jego ciągłym ,stawaniu się”, zlepianiu i nakładaniu na siebie kolejnych palimpsestowych warstw, integrowaniu zróżnicowań, jak również w zwartości i ciągłości (co docenia się dopiero po katastrofalnych skutkach urban sprowl), wreszcie społecznej zań odpowiedzialności. Uważam, że o wartości kulturowej, ponad- czy pozaczasowości miasta świadczy tożsamość jego przestrzeni publicznej wsparta na filarach: trwania, ciagłości, synkretyczności oraz wartości humanistycznych (opartych na Witruwiańskiej triadzie: prostota (umiar), piękno i użyteczność). Ewidentny wpływ na to, jaki miasto ma charakter, jak jest postrzegany miejski krajobraz intencjonalny, jakie wzbudza doznania i emocje, czy jaki obraz mają pod powiekami jego mieszkańcy i użytkownicy, posiada jego fizyczno-kulturowa emanacja, czyli forma architektoniczno-urbanistyczna. A ona najpełniej uwidacznia się i poddaje percepcji we wspólnotowej przestrzeni interakcji społecznych oraz interakcji człowiekprzestrzeń, czyli w przestrzeni publicznej. Przestrzeń publiczna, półpubliczna i jej egzemplifikacje - place (także wewnątrzosiedlowe) i ich pierzeje, fronty budowli, ulice, aleje, bulwary, promenady, zaułki, parki, skwery - z założenia jest dostępna wszystkim, którzy chcą w niej przebywać, spotykać się, doświad-

* Dr, Uniwersytet Wrocławski, Wydział Nauk Społecznych, Instytut Socjologii, 51-149 Wrocław, ul. Koszarowa 3, iborowik@poczta.fm 
czać jej. Podlega zbiorowemu użytkowaniu i przeżywaniu, budowaniu poczucia wspólnoty. Może być zła i nieprzyjazna lub dobra i zapraszająca. W procesach percepcji i waloryzacji, poprzez uznawanie jej za pozytywny symbol, wizytówkę miasta, konstytuuje się poczucie przynależności i identyfikacji z miastem, zadowolenie z życia w tym właśnie mieście. Jak twierdzi, za Hannah A r e nd t, Leon K ri e r (2011), przestrzeń publiczna może być nieśmiertelna, ale ważniejsze, jak sądzę, by była autentyczna (Zu ki n 2010) społecznie i kulturowo, a więc dobra, na swoim miejscu, nie symulakryczna.

Przestrzeń jest cenna. Zazwyczaj też jest czyjaś, do kogoś należy - państwa, narodu, grupy, jednostki. Uznawany na danym etapie rozwoju społecznego ład społeczny legitymizuje tylko proporcje własności - ile prywatnej, a ile państwowej (narodowej). W zideologizowanych miastach socjalistycznych, a takie były polskie miasta przed 1989 r., przestrzeń została upaństwowiona en bloc, nie istniała renta gruntowa, ani prywatna własność. Władza polityczna postrzegana była przez pryzmat architektury - jej potęgę symbolizował rozmach i monumentalizm architektury (por. N aw rate k 2005). W miastach stających się kapitalistycznymi, też zideologizowanych, ale ekonomicznie - wprost przeciwnie, przestrzeń próbuje się za wszelką cenę „urynkawiać” czy prywatyzować (uwłaszczać), uznając jedynie jej wartość ekonomiczna, a władza (ekonomiczna) nadal jest wyrażana prestiżem i wielkością (wysokością) architektury.

$\mathrm{Na}$ przestrzeń publiczną miast - jej kształtowanie i ogląd wpływ ma wiele uwarunkowań, co jest oczywiste, bo przecież jest ona immanentnym elementem miasta. Można rozpatrywać ją z rozmaitych szczegółowych perspektyw: urbanistyczno-architektonicznej, społecznej, antropologicznej, politycznej, ekonomicznej (konsumpcjonizm), estetycznej, psychologicznej, aksjologicznej, ekologicznej itd. O tę przestrzeń grają rozmaici zbiorowi i indywidualni aktorzy, z większymi bądź mniejszymi do niej prawami, pretensjami, oczekiwaniami i potrzebami. Jednak, jeśli przestrzeń miasta jest z zasady uznawana za wspólną i publiczna, to żaden $\mathrm{z}$ aktorów sceny miejskiej nie może przedkładać swojego indywidualnego interesu i rościć sobie do niej tylko swoich praw poprzez dążenie do jej prywatyzowania i zawłaszczania, gdyż jest ona dobrem zbiorowym. Ma być powszechnie dostępna i atrakcyjna dla różnych grup mieszkańców i użytkowników.

W niniejszym artykule rozważaniom została poddana przestrzeń publiczna, ujmowana z perspektywy kilku relacji: społeczeństwo - architektura, przestrzeń publiczna (w rozumieniu formy/funkcji architektonicznej i szerzej - estetycznej) - władza lokalna, oraz przestrzeń publiczna - mieszkańcy i użytkownicy. Poruszono zagadnienia odpowiedzialności za przestrzeń publiczną oraz powrotu do jej zapomnianej roli - przestrzeni służącej szeroko rozumianej wymianie społecznej (w sensie weberowskiego postrzegania miasta). Również nadmieniono o poszukiwaniach dobrej przestrzeni miejskiej poprzez wzmacnianie jej tożsamości architektonicznej i estetycznej na przykładzie centrum Wrocławia - ważnej symbolicznie i prestiżowo przestrzeni publicznej miasta, w celu utrzymania ciągłości 
historycznej i kulturowej miasta, jego autentyczności. Ilustrację empiryczną tych kwestii stanowią mikrobadania dotyczące projektu wrocławskich władz miejskich zwanego „Parkiem Kulturowym Stare Miasto” (B o r o w i k 2015). Owa inicjatywa władz, zmierzająca ku poprawie jakości przestrzeni publicznej miasta, a tym samym wyciaggnięciu ludzi z galerii handlowych i przyciagnięciu do atrakcyjnego kulturowo i społecznie centrum, wpisuje się w nurt działań, który określam metaforycznie i post-gehlowsko: odwracaniem się miasta do ludzi.

\section{Przestrzeń publiczna współcześnie. Kwestie definicyjne i aksjologiczne}

Miejska przestrzeń publiczna jest elementem szerszego porządku, czyli ładu społeczno-przestrzennego, konstytuowanego w oparciu o relacyjność człowiekprzestrzeń. Bardziej szczegółowo ujmowana i traktowana może być, trawestując: romantycznie - jako znacząca wartość kulturowa, symbol kulturowy, wspólne dobro (Gu tow ski 2006; K arwińska 1998), ale i rozważnie, w kategoriach rynkowych - jako produkt, w znaczący sposób budujący markę miasta, także wpływający na jego konkurencyjność (L o r e n s 2007; M a rk ow s k i 1999). Socjologicznie przestrzeń publiczną można ujmować na wiele sposobów, ze względu na jej atrakcyjną poznawczo wielowątkowość rozmaitej proweniencji. Szkicowo i przyczynkowo skupię się na jej formie, czyli funkcji architektonicznej i estetycznej w relacji, interakcji z człowiekiem.

Każda jednostka, która wybiera sobie miejsce do zamieszkania i życia, tworzy przestrzeń ekspresyjną, gdyż wyraża w niej swój aktywny i refleksyjny stosunek do rzeczywistości i przestrzeni fizycznej, zarazem jednak przestrzeń ekspresyjna staje się odbiciem jej obrazu świata. Dzieje się tak, ponieważ człowiek „nadaje swemu otoczeniu znaczenie przez asymilowanie go do swoich celów, równocześnie zaś przystosowuje się (akomoduje) do oferowanych przez nie warunków" (N o r b e r g-S c h u l z 2000: 11). Przestrzeń ekspresyjna urzeczywistnia się zatem w myśleniu o przestrzeni i jednocześnie jej kreowaniu, będącym wyrazem określonych idei i koncepcji przestrzeni. Na gruncie kreacji architektonicznej rodzajem przestrzeni ekspresyjnej, inaczej artystycznej, jest przestrzeń architektoniczna, która „musi adaptować się do potrzeb organicznego działania oraz ułatwiać orientację drogą percepcji. Musi również «ilustrować» pewne kognitywne teorie przestrzeni, na przykład gdy z konkretnych materiałów buduje kartezjański układ współrzędnych. Przede wszystkim jednak związana jest z przestrzennymi schematami indywidualnego i publicznego świata człowieka. [Schematy te człowiek tworzy poprzez] interakcję z istniejącymi przestrzeniami architektonicznymi, a gdy te przestają go zadowalać [...] musi przestrzeń architektoniczną zmienić. A zatem przestrzeń architektoniczną można nazwać konkretyzacją ludzkiej przestrzeni egzystencjalnej" (tamże: 11-12). 
W dokumentach o przestrzeni, polskich i o szerszym zasięgu, typu Karta Ateńska (2003), Karta Lipska (2007), Karta Nowej Urbanistyki (Urbanista 6/2005), Karta Przestrzeni Publicznej (B u c ze k 2011), oraz w obowiązujących przepisach ładu społeczno-przestrzennego nie ma szczegółowych analiz czy rozwiązań dotyczących np. przestrzeni publicznej. Podejmowane są próby definiowania i porządkowania rzeczywistości społeczno-przestrzennej i jej elementów, wyrażane idee i reguły oraz świadomość odpowiedzialności za dzisiaj - jak człowiek bieżąco kreuje tę rzeczywistość, jak też za przyszłość - jaką przestrzeń po sobie zostawi, a taka refleksyjność w dzisiejszej żarłocznej kulturze krótkiego trwania i konsumpcyjnego rozpasania już jest cenna. Czy i jak te postulaty przekładają się na realną codzienność, należy obserwować i analizować zwłaszcza w mikroskali gminnych planów miejscowych dotyczących konkretnych obszarów przestrzeni publicznej miast. Z zadowoleniem przyjąć można dostrzeganie i podkreślanie w rozumieniu przestrzeni, w tym przestrzeni publicznych, wzajemnej relacyjności, interakcyjności człowieka i przestrzeni, wartości humanistycznych i użyteczności społecznej czy społeczeństwa i architektury (świadomość architektoniczna rodzi się z percepcji przestrzeni publicznych właśnie).

Obowiązujące obecnie w Polsce przepisy regulujące organizacje przestrzeni zawarte sa $\mathrm{w}$,Ustawie o planowaniu i zagospodarowaniu przestrzennym z 2003 roku" (Dziennik Ustaw 2003, nr 80, poz. 717). Ład przestrzenny jest w niej rozumiany jako sposób ukształtowania przestrzeni tworzący „harmonijna całość oraz uwzględnia w uporządkowanych relacjach wszelkie uwarunkowania i wymagania funkcjonalne, społeczno-gospodarcze, środowiskowe, kulturowe oraz kompozycyjno-estetyczne". W nim uwidacznia się określony interes publiczny, albo bardziej precyzyjnie - interes rozmaitych aktorów sceny miejskiej. W polskiej rzeczywistości wyzwaniem jest precyzyjne zdefiniowanie interesu czy dobra publicznego. Nie inaczej jest i w tym przypadku, gdyż Ustawa szeroko definiuje ,interes publiczny” jako „uogólniony cel dążeń i działań, uwzględniających zobiektywizowane potrzeby ogółu społeczeństwa lub lokalnych społeczności, związanych z zagospodarowaniem przestrzennym".

Właściwie pojęcie ładu społeczno-przestrzennego kojarzy się raczej z osiągnięciem pewnego stanu, statycznością bardziej aniżeli dynamicznością i zmianą. Przyjmując założenie, że społeczeństwo wciąż „,się staje”, zmienia, rozwija, fluktuuje (S z to m p k a 2002), to faktycznie osiagnięcie ładu, harmonii raz na zawsze może być trudne. Ale jak zapytuje urbanista, twórca nośnego hasła nowego urbanizmu „Miasta dla ludzi” Jan Gehl (i ja do wtóru z nim) - czy nie warto szukać tych wartości, dążyć do nich? Te pragnienia i dążenia napędzają przecież refleksje o otaczającej przestrzeni, jej waloryzację - czy dobra czy zła ta przestrzeń, czy daje poczucie wspólnotowości i bezpieczeństwa, buduje świadomość przestrzenności egzystencji człowieka i kulturowej mocy jego architektonicznej kreacji.

Wreszcie pojęcie kluczowe z racji podjętego tematu rozważań - przestrzeń publiczna. Stanowi ją zgodnie z Ustawą (2003) „obszar o szczególnym znaczeniu 
dla zaspokojenia potrzeb mieszkańców, poprawy jakości ich życia i sprzyjający nawiązywaniu kontaktów społecznych ze względu na jego położenie oraz cechy funkcjonalno-przestrzenne, określony w studium uwarunkowań i kierunków zagospodarowania przestrzennego gminy". W krytycznych analizach Ustawy (B u c ze k 2011) podkreśla się, iż gminy często nie stosują się do przepisów nowej ustawy i nie wydzielają uznanych za szczególne obszarów przestrzeni publicznej. Wybierają starą ustawę z 1994 r., niezawierającą tego wymogu, ponadto jako przestrzenie publiczne wskazują wcale nie te najważniejsze miejskie miejsca, „czego szczególnym przykładem jest Warszawa: obszarami przestrzeni publicznej wg Studium Warszawy z października 2006 r. nie są np. Plac Piłsudskiego czy Plac Zamkowy, a jest nią np. rejon ronda im. Dżochara Dudajewa w dzielnicy Włochy... Faktyczne obszary przestrzeni publicznej to zwykle rejony bardzo atrakcyjne i pozostające $\mathrm{w}$ centrum zainteresowania inwestorów nieruchomościowych, można więc założyć, iż są one celowo nie poddawane obligatoryjnej procedurze planistycznej, umożliwiającej wszystkim zainteresowanym partycypowanie w ich kształtowaniu. Są natomiast nazbyt często kształtowane/przekształcane przy pomocy arbitralnych decyzji administracyjnych (tj. obu rodzajów decyzji o warunkach zabudowy i zagospodarowania terenu), których wydawanie jest zasadniczo ograniczone przez wskazany wyżej przepis o obowiązku planistycznym. [...] A przecież ustawodawca wyraźnie stwierdził, że [...] w planie miejscowym określa się obowiązkowo [...] wymagania wynikające z potrzeb kształtowania przestrzeni publicznych" (B u c ze k 2011). To oznacza, iż przestrzeń publiczna, pozostając głównie w gestii władz samorządów, mocniej jeszcze jest zawłaszczana przez urzędników. A oni, zasłaniając się interesem społecznym i wspólnotowym, sami chcą decydować o własności, kształcie i jakości przestrzeni publicznych miasta. Częste, szczególnie w początkowym okresie zmiany polskich miast (lata 90. XX wieku), było szukanie jak najłatwiejszego i najlepszego, zdaniem władz miejskich, rozwiązania dla budżetu i rozwoju miasta, poprzez bezmyślne sprzedawanie gruntów i tworzenie reżimu miejskiego (S a g a n 2000) z deweloperami, lokalnym i ponadlokalnym biznesem nieruchomości. Takie szafowanie i niszczące spójność dzielenie przestrzeni publicznej spowodowało jej fragmentaryczność oraz ,umycie rąk” przez władze poprzez zrzucenie za nią odpowiedzialności na aktorów biznesowych.

Z Karty Lipskiej (2007: 4) płyną głęboko humanistyczne i społeczne nawoływania dotyczące jakości architektury przestrzeni publicznych, czyli miejskich krajobrazów wpływających na warunki i jakość życia ludności miejskiej.

Jako «miękkie czynniki lokalizacji» odgrywają one ważną rolę w przyciąganiu przedsiębiorstw opartych na wiedzy, wykwalifikowanej i twórczej siły roboczej oraz turystyki. Dlatego należy zwiększyć wzajemne oddziaływanie architektury, planowania infrastruktury i planowania miejskiego, aby stworzyć atrakcyjne, przyjazne dla użytkownika przestrzenie publiczne i osiągnąć wysoki standard środowiska życia - kultury budowlanej (Baukultur). Kulturę budowlaną powinno się rozumieć w najszerszym znaczeniu tego słowa, jako sumę wszystkich 
aspektów kulturowych, gospodarczych, technologicznych, społecznych i ekologicznych, które wpływają na jakość i proces planowania oraz budowania. Jednak podejście to nie powinno ograniczać się do przestrzeni publicznych. Taka «kultura budowlana» jest potrzebna dla miasta jako całości i jego okolic. Zarówno władze miejskie, jak i rządowe muszą sprawić, aby wywierany przez nie wpływ był odczuwalny. Jest to szczególnie ważne dla zachowania dziedzictwa architektonicznego. Budynki historyczne, przestrzenie publiczne oraz ich wartość miejska i architektoniczna muszą zostać zachowane.

W Karcie Nowej Urbanistyki także postulowana jest prowspólnotowa restrukturyzacja społeczno-przestrzenna miast $i$ ich przestrzeni publicznych zgodnie z określonymi zasadami:

Dzielnice powinny być zróżnicowane pod względem pełnionych funkcji oraz grup mieszkańców; wspólnoty te powinny być projektowane z myślą o pieszych, transporcie publicznym i ruchu samochodowym; elementem kształtującym miasta powinny być obszary publiczne i instytucje wspólnotowe wyraźnie przestrzennie określone i powszechnie dostępne; przestrzenie miejskie powinny być kształtowane przez projektowanie architektoniczne i krajobrazowe eksponujące lokalną historię, klimat, ekologię oraz tradycję budowlaną. Podstawowym zadaniem projektowania architektury i krajobrazu miejskiego jest przestrzenne zdefiniowanie ulic i przestrzeni publicznych, jako obszarów wspólnego użytkowania (Urbanista 6/2005: 8-10).

Rozumienie przestrzeni publicznej jako wspólnego dobra, wartości musi być uwewnętrznioną refleksją i potrzebą aktorów społecznych, w przeciwnym razie jej wspólność pozostanie pustym frazesem.

Piotr Lorens ze swoją kategoryzacją przestrzeni publicznej na społeczna, własnościową i formalistyczną wpisuje się w moje postrzeganie przestrzeni publicznej. Ujmuje ją jako:

fragment przestrzeni miejskiej, który - poprzez sposób swojego urządzenia oraz lokaliza-
cji w strukturze urbanistycznej - przeznaczony będzie na potrzeby realizacji bezpośrednich
kontaktów pomiędzy uczestnikami życia społecznego oraz innych potrzeb społecznych ko-
rzystających z niej zbiorowości, pozostając jednocześnie fizycznie dostępnym dla wszystkich
zainteresowanych osób. Fizyczna dostępność przestrzeni może być ograniczana czasowo
z uwagi na kwestie bezpieczeństwa bądź sposobu organizacji jej wykorzystania (L o ren s,
M arty n i u k-P ę c z e k 2010:10).

Podkreśla w swym rozumieniu interesującego pojęcia aspekt społeczny:

[N]ajbardziej istotną cechą przestrzeni publicznej będzie wciąż jej publiczność, choć nie rozumiana już jako forma własności, ale jako możliwość nawiązywania bezpośrednich kontaktów interpersonalnych, w tym pomiędzy osobami nie znającymi się wcześniej (L o r e n s 2007: 86).

Bowiem rzeczywiście socjologiczną istotą kategorii ,przestrzeń publiczna" jest jej bycie forum/agorą (choć coraz częściej przenoszoną do wirtualnej rzeczywistości) oraz posiadanie publiczności. To oznacza otwartość i dostępność dla każdego (nie do końca), możliwość spotkań, wymiany szeroko rozumianej - ekonomicznej, politycznej i społecznej, stykanie się relacji państwo-obywatel (jak np. we współczesnych przypadkach - Stambułu, Kijowa czy Kairu - plac 
miejski posiadał istotne znaczenie $\mathrm{w}$ walce $\mathrm{z}$ totalitaryzmem). Choć dla Richarda Sennetta (2009) właśnie w sferze kontaktów, interakcji, wymiany, zredefiniowaniu i przewartościowaniu uległy przestrzeń publiczna i prywatna. Najkrócej rzecz ujmując - wymieszały się, a nawet zamieniły rolami - to, co działo się zazwyczaj w przestrzeni publicznej, współcześnie ma miejsce w przestrzeni prywatnej i odwrotnie. Ponadto, otwartość i dostępność przestrzeni publicznej dla tzw. ogółu nie oznacza, że nie obowiązują w niej określone zasady regulujące zachowania społeczne i dające poczucie bezpieczeństwa. Ta przestrzeń jest współdzielona z innymi, więc wolność i swoboda jednostki kończy się tam, gdzie zaczyna wolność i swoboda innej jednostki.

Kiedy na miejską przestrzeń publiczną spojrzy się też z perspektywy strukturalnej, wyraźnie będzie widać, że łączy w sobie dwa zasadnicze podsystemy miejskie wyróżnione przez Aleksandra Wallis a (1971) - społeczny i urbanistyczny, co tylko podkreśla relacyjność, sprzężenie i synkretyczność elementów społecznych i przestrzennych (architektoniczno-urbanistycznych), oraz wzajemną dostępność. Jest to warunek sine qua non istnienia przestrzeni publicznych miasta - bez ludzi są martwe. Co z tego, że jest pięknie, bo po renowacji i rewitalizacji (od re-vitae, czyli przywrócenie do życia (sic!), po wyłączeniu ruchu samochodowego, kiedy nie ma po co tam iść i być, czyli, jak mawiają urbaniści - brakuje miejskich atraktorów. Trzeba przestrzenie publiczne zatem tak organizować, by były zapraszające, przyjazne i atrakcyjne, by ludzie pozytywnie je postrzegali i chcieli przebywać na rynku, placach i ulicach, a nie tylko w centrach handlowych czy rozrywkowych, a to już przestrzeń publiczna nie jest, tylko przestrzeń prywatna udostępniana publicznie.

\section{Przestrzeń publiczna - jak wspólna, to niczyja?}

W ideowych dokumentach oraz ogólnikowych paragrafach ustawy o kształtowaniu i zarządzaniu przestrzenią zawarte są wartościowe spostrzeżenia i wytyczne wskazujące na potrzebę zredefiniowania podmiotowości współczesnych miast. Miasta, aby nie stawały się coraz częściej anty-miastami, patchworkami miejskimi, jak to trafnie ujęła Ewa R ew e r s (2007), potrzebują ponownego renesansu, by można było w nich wygodnie i przyjaźnie żyć, by posiadły/odnowiły swój charakter, ducha, indywidualizm i tożsamość, kreatywność (L a ndry 2005-2007; D e ha en e, D e Carter 2008; Got t d i e ner, Hu tc hin son 2011). Mają być zdecydowanie antymodernistyczne, bo - zróżnicowanie, policentryczność i tradycja; ukazujące znaczenie współkreowania przez rozmaitych aktorów oraz współodpowiedzialności za dobro wspólne, jakim jest, nie - obszar zurbanizowany, nie - machina wzrostu, ale pluralistyczne, dobrze zorganizowane miasto, jako miejsce dla rozmaitych zbiorowości. Uważam, że tę współodpowiedzialność należy oprzeć na fundamentach zaufania społecznego i solidarności społecznej. 
Bez nich niemożliwy jest społeczny sojusz, współpraca nad jakością oraz wspólnotowość („nasza”) przestrzeni publicznych. Aczkolwiek biorąc pod uwagę heterogeniczność społeczną i skalę dużego miasta, np. Wrocławia, oraz ogólnie niski poziom zaufania społecznego, ale jednak nie najgorszy do władz i ich instytucji (ufa im nieco ponad $50 \%$ badanych wrocławian), nie będzie to łatwe, choć nie niemożliwe (K a j d a n ek 2014).

Wyniki badań osiedli wrocławskich (np. Borowik 2003) czy badań Wrocławskiej Diagnozy Społecznej 2014 (Kłopot i in. 2014) ukazują słabnące relacje sąsiedzkie, wyrażające się w stosunku do przestrzeni wspólnie użytkowanej jako ziemi niczyjej. Przy wspólnych przedsięwzięciach uczestnicy się rozglądają kto pierwszy coś zrobi, zaproponuje, jak coś nie wyjdzie, to nie ma winnych - świetnie funkcjonuje mechanizm rozproszonej odpowiedzialności. Dlatego w polskim, dojrzewającym wspólnotowo społeczeństwie dostrzegam potrzebę wyraźnego wskazywania koordynatorów działań, liderów oraz legitymizacji odpowiedzialności za kształtowanie i jakość przestrzeni publicznej.

Powyżej scharakteryzowane potrzeby dostrzegają architekci i urbaniści, którzy biorą na siebie ciężar odpowiedzialności za kreowanie i organizowanie przestrzeni miejskich. Jako specjaliści poddają refleksji otaczającą przestrzeń, głębiej i mocniej widzą znaczenie przestrzeni publicznej miast, jak również swoją rolę w tworzeniu przestrzeni publicznych oraz dyktowaniu nierzadko, jaka ona powinna być. Miasto, a zatem również przestrzeń publiczna, to według niektórych z nich nie jest pole do eksperymentów (K r i e r 2011) czy zabawa architektoniczna (L o e g le r 2000). Z tej potrzeby przemyślenia miasta, miejskości - jego formy wpływającej na sposoby i style życia zbiorowości miejskich - objawił się Nowy Urbanizm (A m i n, T hrift 2002; L a n d r y 2005-2007; M a j e r 2014), ale głosy przestrzegające przed ponowną ideologizacją przestrzeni miast nie cichną $(\mathrm{Na}$ wratek 2010; Krier 2011; P a s k ow sk i 2011). Projektanci mają teź świadomość, że w pogoni za klientami, schlebianiu gustom, pod presją atrakcyjności i wywierania wrażenia skupili się na kopiowaniu kulturowym, symulakrowaniu i budowaniu dekoracji, a nie na kreacji architektonicznej zgodnej z kontekstem przestrzennym, kulturowym i społecznym, powołującej miejsca autentyczne (Ghirard o 1999; Ec o 1998; Lorens 2007).

Ograniczone rozumienie miasta tylko w kategoriach rynkowych, jako machiny wzrostu, charakterystyczne dla okresu zmiany polskich miast po 1990 roku, doprowadziło do ograniczenia roli interesu społecznego - czyli potrzeb mieszkańców i uwzględniania go w procesach decydowania o przestrzeni miasta a wzmocnienia prawa do miasta elit gospodarczych i politycznych. Na przykładzie Warszawy badacze miejskiej rzeczywistości pokazali (Jałowiecki i in. 2009), że stolica należy do urzędników i deweloperów, a zdaniem architektów i urbanistów wręcz do nikogo. Urzędników, gdyż ignorują plany zagospodarowania miejscowego i pozwalają budować w górę, a deweloperów, bo pozostawiono im swobodę w grze rynkowej i rozdrapywaniu jeszcze wolnych przestrzeni pod 
biurowce i apartamentowce, tym samym przyzwalając na prywatyzację przestrzeni publicznej.

Współcześnie jednak widoczna jest większa pokora lokalnych władz, niejako wymuszona rosnącą mobilizacją i aktywizacją ruchów miejskich (nowych aktorów w grze o miasto), rozwojem nowych mediów w sensie nowej agory, wzrostem świadomości przestrzennej mieszkańców i użytkowników miast (może niezbyt zauważalnym przez architektów, ale w badaniach świadomości architektonicznej bardziej, por. badania CBOS z 2010 i 2014). Postulowane zmiany odrodzeniowe miasta, a zatem również roli i funkcji przestrzeni publicznej, rozumiane jako branie odpowiedzialności za swoje miejsce życia, mieszkania czy pracy (H a r v e y 2012), wskazuje, iż mieszkańcy i użytkownicy miast to nie tylko bierna publiczność, ale i zaangażowani obywatele miejscy roszczący sobie prawo do decydowania o mieście i jego rozwoju (por. lokalne wrocławskie doniesienia medialne dotyczące protestu mieszkańców Maślic, czy listu do władz miejskich z lutego 2012 i dyskusji wokół EURO 2012 i Stadionu Miejskiego - miasto dla turystów czy mieszkańców, kontrowersji wokół wieżowca Sky Tower, Wrocławia jako Europejskiej Stolicy Kultury itp.).

Dzięki temu, że miasta otwierają się na mieszkańców i umożliwiają formułowanie swoich interesów (np. za sprawą wprowadzania budżetów partycypacyjnych), mieszkańcy coraz odważniej z tych możliwości korzystają. To właśnie przez aktywność w przestrzeni publicznej mieszkańcy są w stanie działać dla zaspokojenia swoich potrzeb, czyli aktywizować się wokół interesów i przyciągać do siebie coraz szersze grono współmieszkańców. Wzrost aktywności mieszkańców narasta i stają się oni coraz istotniejszą grupą (grupami) interesu w mieście (Kaj d a n e k 2014: 4).

Kolejny przykład stanowią naciski specjalistów i mieszkańców dotyczące chaosu urbanistycznego w polskich miastach, nadmierności reklam, szczególnie wielkoformatowych zasłaniających architekturę, zabytki, po prostu miasto sprawiło, iż władze lokalne i ponadlokalne (Prezydent RP) zajęły się rozwiązywaniem tych problemów w przestrzeniach publicznych. Władze Wrocławia przyjęły w tej kwestii pewne działania, na przykład utworzenie Parku Kulturowego „Stare Miasto" i walkę z nadmiarem reklam w znaczących przestrzeniach publicznych miasta.

Władza często jest postrzegana (i nie bez racji) jako zbiór rytualistów (w sensie Mertonowskiej koncepcji anomii), niedostrzegających już celów kulturowych, tylko skupiających się na procedurach, przepisach i legitymizacji swojego bycia oraz trwania. Dlatego wywieranie presji oraz działania mieszkańców, ich stowarzyszeń pokazujących prawdziwe życie, są drogą wpływania na postępowanie władzy, jej sposoby myślenia o mieście i zarządzania nim. Ale aktywność mieszkańców w ich przestrzeni egzystencjalnej przynosi również dla tej przestrzeni opłakane skutki. Przykładem nasz narodowy fenomen grodzenia osiedli, kamienic, bloków przez mieszkańców czy deweloperów, który paradoksalnie jest właśnie rezultatem brania odpowiedzialności za to, co moje, nasze - nasza przestrzeń, 
moje miejsce. Jednocześnie skutkuje pogłębianiem fragmentacji przestrzeni miejskiej, dzieleniem i domykaniem przestrzeni publicznych i półpublicznych, rozrywaniem sąsiedztwa, skupienia społecznego, swobody wymiany społecznej, już i tak niszczonej sukcesywnie w miastach poprzez budowanie „w górę”, wysokościowe. Przykładem działania fragmentującego przestrzeń, pomijającego konsultacje z gronem specjalistów (choćby urbanistów), ilustrujaceego zawłaszczenie przestrzeni przez dominujące dwa podmioty: władze i biznes, było kuriozalne wydanie zgody władz Wrocławia na wybudowanie najwyższego (nie najpiękniejszego niestety) budynku w Polsce, czyli 212-piętrowego wysokościowca Sky Tower. Zachwiał on istniejącym ładem przestrzennym, jego czytelnością gdyż stercząc samotnie, nie tworzy i nie podkreśla społecznej, przestrzennej, kulturowej czy estetycznej funkcji określonego obszaru miasta, nie wpisując się swoim kształtem i wielkością w skalę oraz krajobraz intencjonalny stolicy Dolnego Śląska. Również tzw. ogródki kawiarniane i restauracyjne przyczyniają się do fragmentacji przestrzeni publicznej, ograniczając ją i wyznaczając dla wybranych użytkowników miasta, także zwiększając chaos estetyczny i urbanistyczny, czy nierzadko zasłaniając piękno architektury. $Z$ drugiej strony, tworzą miejsca szeroko rozumianej wymiany społecznej, których bardzo potrzeba w przestrzeni publicznej polskich miast $-70 \%$ badanych oczekuje, iż w rynku, centrum Wrocławia będzie więcej miejsc służących spotkaniom, odpoczynkowi, doznaniom kulturowym czy kontemplacji pięknego otoczenia (B o r o w i k 2015). Takie miejsca unaoczniaja, że miasto żyje, zaprasza do otwartych, prawdziwych przestrzeni publicznych, do spotkania z ludźmi, architektura, sztuką, zielenią, niebem i słońcem.

\section{Czyj jest Wrocław?}

Wiosną 2015 roku, w ramach zajęć „Kulturowy wymiar przestrzeni i architektury", zostały wykonane przez studentów II roku socjologii Uniwersytetu Wrocławskiego (we współpracy z UM Wrocławia) mikrobadania przestrzeni publicznej Wrocławia. Głównie dotyczyły one miejskiej inicjatywy powołania parku kulturowego. Utworzony ,w celu ochrony krajobrazu kulturowego oraz zachowania wyróżniających się krajobrazowo terenów z zabytkami nieruchomymi charakterystycznymi dla miejscowej tradycji budowlanej i osadniczej" (Uchwała nr LVI/1465/14 Rady Miejskiej Wrocławia, z dnia 10 kwietnia 2014 r.). Wrocławski Park Kulturowy „Stare Miasto" obejmuje swym zasięgiem: Rynek, Wyspy Odrzańskie, Ogród Botaniczny, Ostrów Tumski, Promenadę Staromiejska, park Słowackiego oraz plac Kościuszki. Ta centralna przestrzeń ma być wolna od reklam wielkoformatowych zasłaniających architekturę miasta, jednocześnie estetyczna i przyjazna, służyć rozmaitym aktorom: mieszkańcom, przedsiębiorcom, właścicielom nieruchomości oraz turystom. Ograniczanie reklam i walka z graffiti w przestrzeni publicznej oznacza pokazanie ulicy, odsłonięcie architektury i przywrócenie znaczenia witrynom sklepowym. Oznacza również zmianę statusu ulicy, placu, rynku i ich pierzei z wieszaków reklamowych na miejsca przyciagające swoją estetyką i sprzyjające relacjom społecznym. 
W badaniu (B o row i k 2015) wzięło udział 286 osób, głównie z wykształceniem średnim $(45,8 \%)$ i wyższym $(33,9)$, w przedziale wieku 16-30 lat $(59,4)$, codziennie $(28,3 \%)$ lub kilka razy w tygodniu $(25,5)$ bywających na Starym Mieście. Nieco ponad 38\% respondentów stanowili mieszkańcy Wrocławia, 22,7\% osoby uczące się we Wrocławiu, a 14,3 \% osoby w nim pracujące. Więcej kobiet (55\%) aniżeli mężczyzn zgodziło się przedstawić swoją opinię. A zapytano osoby zamieszkujące i użytkujące obszar Starego Miasta, między innymi o ich stanowisko wobec przestrzeni publicznej - „Czym jest według Pana/i przestrzeń publiczna miasta (place, ulice)"? i wybranie z kafeterii od jednej do trzech możliwych odpowiedzi. Około $70 \%$ badanych, głównie młodych ludzi w przedziale 16-25 lat, sporo mniej 30- i 40-latków, z wykształceniem średnim i wyższym, odpowiedziało, że przestrzeń publiczna miasta jest dobrem wspólnym, należy do wszystkich mieszkańców i użytkowników oraz władz. 65\% uważa, że jest wizytówką miasta. Również znacząca większość respondentów (ok. 70\% wskazań), w szczególności kobiety, nie ma poczucia, że przestrzeń publiczna Wrocławia jest zawłaszczana przez przedsiębiorców, np. firmy deweloperskie i zarządzające nieruchomościami (B o r o w i k 2015).

Zatem przestrzeń publiczna Wrocławia jest deklaratywnie uznawana przez respondentów za „naszą”, „,wspólną”. Młodzi, wykształceni ludzie są przeświadczeni, że przestrzeń publiczna miasta należy do wszystkich: do mieszkańców i użytkowników, do władz coraz chętniej wsłuchujących się w głosy obywateli miasta i do przedsiębiorców częściej uwzględniających szerszy, społeczny kontekst swojej działalności oraz interes publiczny. Stanowi to empiryczne potwierdzenie, iż przestrzeń publiczna jest złożoną, wielowątkową strukturą, dorobkiem społecznym i wartością kulturową. Jest miasta emanacją. Sama nazwa wskazuje jej immanentne własności: jest nie-prywatna, otwarta i dostępna, wspólnie użytkowana, co jest wyraźnie odczytywane przez osoby badane. Między innymi w Karcie Lipskiej (2007) wyraźnie zaznacza się, kto jest odpowiedzialny za tworzenie, jakość i ochronę przestrzeni publicznych dobrze i funkcjonalnie zaprojektowanych: władze lokalne, regionalne i państwowe, przedsiębiorstwa i obywatele. Zatem tak przestrzeń publiczną należy traktować - jako dobro społeczne, zarządzane przez odpowiedzialne (nie tylko rynkowo, ale i społecznie) samorządy lokalne, na które wpływ mają świadomi swoich praw mieszkańcy (obywatele miejscy?). Przy czym czas na rozważania ideowe i pobożne życzenia już się wypełnił, pora najwyższa na działania.

\section{W poszukiwaniu dobrej przestrzeni publicznej i jej tożsamości estetycznej}

Pokazanie tożsamości estetycznej, historycznej i prestiżowej części Wrocławia władze miejskie chcą osiągnąć poprzez mocniejsze administracyjne dopilnowanie porządku, czytelności przestrzeni, ładu estetycznego i ukazanie jej 
architektonicznego piękna, zaczynając walkę z wszechobecnymi reklamami. Większość osób zapytanych o obecność w tej przestrzeni reklam uważa, podobnie jak władze lokalne, że jest ich tam za dużo (ok. 50\% wskazań), aczkolwiek ponad połowie respondentów obecność reklam specjalnie nie przeszkadza, a 24\% nie ma zdania w tej kwestii. Respondenci nie uznają też centralnej części miasta za nieczytelną i chaotyczną wizualnie (78\%). 20\% badanych, którym reklamy jednak przeszkadzają $\mathrm{w}$ centralnej przestrzeni publicznej miasta, podkreśla, że reklamy, szczególnie wielkoformatowe, zasłaniają budynki, architekturę, ponadto niszczą je oraz zaśmiecają miasto, a także mają negatywny wpływ na percepcję przestrzeni miejskiej, jej piękno.

Wrocławskie badania pokazały, że mieszkańcy i użytkownicy centralnej przestrzeni publicznej Wrocławia za podstawowy atut miasta uznają urodę Starego Miasta, głównie ze względu na jego historyczną architekturę (25,5\%), co potwierdza ciagge pozytywne społeczne postrzeganie i waloryzowanie zabytków oraz docenianie dawnego kunsztu architektonicznego. Opinie badanych są natomiast podzielone co do kwestii, iż przestrzeń Starego Miasta wymaga poprawy/ zmiany w zakresie zadbania o jej czystość i estetykę (40\%), ale ze wskazaniem, że raczej jest zadbana i estetyczna (60\%).

Ewidentnie centralny obszar miasta wyznaczony jako park kulturowy jest traktowany przez badanych jako przestrzeń wymiany i kontaktów, jako że najczęściej wskazywane funkcje tego fragmentu miasta to w kolejności wskazań: handlowa, gastronomiczna, rozrywkowa/rekreacyjna oraz artystyczno-kulturowa. Wielość i różnorodność restauracji, kawiarni, barów, pubów, nocnych klubów, galerie sztuki, wystawy uliczne, koncerty, kwiaciarnie na pl. Solnym, częste jarmarki i stosunkowo dużo miejsc handlu, a wszystko to w pięknej oprawie architektonicznej - przyciagają użytkowników i mieszkańców. Jednak, według nich, wciąż za mało jest miejsc sprzyjających kontaktom społecznym, możliwościom pobycia w pięknym otoczeniu, zatem respondenci postulują zwiększenie liczby ogólnodostępnych miejsc odpoczynku, mebli miejskich i elementów artystycznych - ławek, donic z zielenią, kompozycji kwiatowych, fontann, murali artystycznych, rzeźb, wystaw ulicznych.

Koncepcja parku kulturowego, poparta odpowiednimi regulacjami administracyjnymi chroniącymi miejski krajobraz intencjonalny, podkreśla znaczenie centralnej, wartościowej kulturowo i estetycznie, zabytkowej, „salonowej” części miasta, która także współcześnie, pomimo, a może właśnie ze względu na procesy decentralizacyjne polskich miast, powinna wciąż mocno tętnić życiem. Rozumiem tę ideę parku kulturowego również jako drogę poszukiwania dobrej przestrzeni publicznej, czyli: synkretycznej - poprzez łączenie lokalnych elementów historycznych i nowoczesnych, materialnych i społecznych; przestrzeni tak zaprojektowanej/odnowionej/zrewitalizowanej, aby stanowiła odbicie oczekiwań społecznych; czytelnej oraz wysoce (wzorcotwórczo) estetycznej. Utworzenie parku kulturowego i oczyszczenie miasta z wizualnego chaosu to dopiero dość 
prosty początek drogi ku tworzeniu dobrej przestrzeni publicznej, przestrzeni wyrazistej, charakterystycznej, autentycznej, umocowanej w danym kontekście kulturowym, wspólnie dzielonej, która będzie stawała się miej s cem. Ale te działania pokazują (nareszcie!) zainteresowanie władz lokalnych estetyką przestrzeni pozostającej pod ich jurysdykcją. Ponadto, poprzez sięganie do tradycji i korzeni tożsamości kulturowej miasta oraz wprowadzanie nowych elementów kulturowych, są jakąś reakcją na powszechną nijakość, amorficzność, totalność i standardowość przestrzeni publicznych.

\section{Bibliografia}

A m in A., Thrift N. (2002), Cities. Reimagining the Urban, Polity Press, Cambridge.

B o r o wik I. (2003), Blokowiska - miejski habitat w ogladzie socjologicznym. Studium jakości wrocławskich środowisk mieszkaniowych, Arboretum, Wrocław.

B or ow ik I. (2015), Raport z badań przestrzeni publicznej Wroctawia. Park Kulturowy „Stare Miasto", materiał niepublikowany.

B u c z e k G. A. (2011), Przestrzeń publiczna a jakość życia i zamieszkiwania, Urbanistyka.info.

CBOS Komunikat z badań (2010), Polacy o architekturze, Warszawa.

CBOS Komunikat z badań (2014), Polacy o architektach, Warszawa.

D e h a e n e M., D e C a r t e r L. (2008), Heterotopia and the City. Public Space in a Post-civil Society, Routledge, London and New York.

E c o U. (1998), Semiologia życia codziennego, Czytelnik, Warszawa.

G h i r a r d o D. (1999), Architektura po modernizmie, Wydawnictwo VIA, Torun-Wrocław.

G ot t d i e n e r M., H u t c h i n s o n R. (2011), The New Urban Sociology, Fourth Edition, Westview Press.

G u to w s k i B. (2006), Przestrzeń marzycieli. Miasto jako projekt utopijny, pdf.

Harvey D. (2012), Bunt miast. Prawo do miasta i miejska rewolucja, Fundacja Bęc Zmiana, Warszawa.

J ałow i ecki B., S e kuła E. A., S męt tkow ski M., Tucholska A. (2009), Warszawa. Czyje jest miasto?, Scholar, Warszawa.

K a j d a n e k K. (2014), Diagnoza aktywności obywatelskiej mieszkańców Wrocławia, raport tematyczny Wrocławskiej Diagnozy Społecznej, Wrocław.

Karta Lipska na rzecz zrównoważonego rozwoju miast europejskich (2007), pdf, Lipsk.

Karta Nowej Urbanistyki (2005), Urbanista, 6, pdf.

K a rwiń s k a A. (1998), Wartości i potrzeby społeczne a przemiany środowiska miejskiego, „Zeszyty Ekonomiczne AE w Krakowie", Seria Specjalna: Monografia Nr 136, Kraków.

Kło p ot S. W., K o z d r a ś G., P l u t a J., Troj a n o w s k i P. (2014), Raport z badań socjologicznych nad mieszkańcami miasta. Wrocławska Diagnoza Społeczna 2014, Wrocław, sierpień.

K r i e r L. (2011), Architektura wspólnoty, Wydawnictwo słowo/obraz terytoria, Gdańsk.

L a n d r y Ch. (2005-2007), Creativity and the City Thinking Throught the Steps, The Urban Reinventors Paper Series, pdf

L o e g l e r R. (2000), Miasto to nie architektoniczna zabawa, „Tygodnik Powszechny on line”.

L o r en s P. (2007), Tematyzacja przestrzeni publicznej jako wyraz dywersyfikacji struktury urbanistycznej miasta doby globalizacji, [w:] M a d u row i c z M. (red.), Percepcja wspótczesnej przestrzeni miejskiej, Wyd. WGiSR UW, Warszawa, s. 83-92.

L or e n s P., M a rty ni u k-P ę c ze k J. (red.) (2010), Problemy ksztaltowania przestrzeni publicznych, Wydawnictwo Urbanista, Gdańsk. 
M a j e r A. (2014), Odrodzenie miast, Scholar, Warszawa-Łódź.

M a r k o w s ki T. (1999), Zarzadzanie rozwojem miast, PWN, Warszawa.

$\mathrm{N}$ a w r a te k K. (2005), Ideologie w przestrzeni. Próba demistyfikacji, Universitas, Kraków.

$\mathrm{N}$ o r b e r g-S c h u 1 z Ch. (2001), Bycie, przestrzeń, architektura, Wydawnictwo Murator, Warszawa.

Nowa Karta Ateńska 2003. Wizja miast XXI wieku (2003), Europejska Rada Urbanistów, Lizbona, pdf.

P a s z o w ski Z. (2011), Miasto idealne w perspektywie europejskiej i jego zwiqzki z urbanistyka wspótczesna, Universitas, Kraków.

R e w e r s E. (2007), Od fragmentacji do integracji: Analiza kulturowa miejskiego patchworku, [w:] M a d u row i c z M. (red.), Percepcja współczesnej przestrzeni miejskiej, Wyd. WGiSR UW, Warszawa, s. 73-82.

S a g a n I. (2000), Miasto. Scena konfliktów i wspótpracy. Rozwój miast w świetle koncepcji reżimu miejskiego, Wydawnictwo Uniwersytetu Gdańskiego, Gdańsk.

S e n n e t t R. (2009), Upadek czlowieka publicznego, MUZA SA, Warszawa.

S z to m p k a P. (2002), Socjologia. Analiza społeczeństwa, Wydawnictwo Znak, Kraków.

Uchwała nr LVI/1465/14 Rady Miejskiej Wrocławia, z dnia 10 kwietnia 2014 r.

Ustawa o planowaniu i zagospodarowaniu przestrzennym, z dnia 27 marca 2003 r., Dz. U. 2003, $\mathrm{Nr} 80$, poz. 717.

Wa 11 is A. (1971), Socjologia i ksztaltowanie przestrzeni, PIW, Warszawa.

Zu k in S. (2010), Naked City: The Death and Life of Authentic Urban Places, Oxford University Press, New York.

\section{Iwona Borowik}

\section{THE LOCAL AUTHORITY IN SEARCH OF THE GOOD PUBLIC SPACE}

Abstract. Author is focused on the issue of relations: the public urban space (as form/function architectural) and the local authority and inhabitants. The article presents problems: responsibility of inhabitants for their city; privatisation and fragmentation of the urban public space; reinforcement of aesthetical and architectural identity of important (symbolical and prestigious) part of public space - city centre.

Key words: post-socialistic city, architectural space, (good) public space, social and spatial order, privatisation and fragmentation of the urban public space, cultural park. 